\title{
Peranan KKN sebagai Perwujudan Penerapan Pengetahuan Tentang Pengolahan Jagung kepada Masyarakat Desa Bleberan, Kabupaten Gunungkidul
}

\author{
Aldidarichie Prindi Chandra ${ }^{1}$, Beatrix Oktaviani Towa ${ }^{2}$, Devineta Niken Salsabilla ${ }^{3}$, Galang Ariesta Nugraha ${ }^{4}$, I Gusti Ngurah David \\ Prasetya ${ }^{5}$, Lidya Christine Pasaribu ${ }^{6}$, Pramana Anantasadhu ${ }^{7}$, Sandy Marcellino ${ }^{8}$, Valencia Yuniarti Sutjiato ${ }^{9}$, Valens Karel Bramasta ${ }^{10}$ \\ Universitas Atma Jaya Yogyakarta, Jalan Babarsari No. 44, Kabupaten Sleman, Daerah Istimewa Yogyakarta \\ Email: didit.gunawan@uajy.ac.id
}

Received: June $12^{\text {th }} 2021$; Revised: November 28 ${ }^{\text {th }}$ 2021; Accepted for Publication November 29th 2021; Published: November $29^{\text {th }} 2021$

\begin{abstract}
Kuliah Kerja Nyata $(\mathrm{KKN})$ is an educational activity in higher education as a form of academic activity related to community service programs. One of the villages is the location for organizing KKN, namely Bleberan Village, Playen District, Gunungkidul, D.I. Yogyakarta. The result of food crops with the largest commodity in this village is corn. This can be seen as a big enough potential for the people of Bleberan Village. One of the products that is very likely to be produced from the corn plant is food products. Easy-to-cultivate corn plants also allow rural communities to carry out the processing process independently. Therefore, the role of KKN as a manifestation of the application of knowledge about corn processing is important for the people of Bleberan Village. It is intended that the villagers can further develop and maximize the processing of corn and economical commercial value that can help build the economy in the Bleberan Village. The method used in this journal is qualitative research. The method of collecting data sources used is using secondary data collection methods collected via the internet, documentation of the conversations of the author's team through online means such as Whatsapp groups and Microsoft Teams, as well as references from other sources.
\end{abstract}

Keywords - The Role of KKN, Processed Corn, Bleberan Village

\begin{abstract}
Abstrak - Kuliah Kerja Nyata (KKN) merupakan kegiatan pendidikan pada perguruan tinggi sebagai bentuk kegiatan akademik yang berkaitan dengan program pengabdian masyarakat. Salah satu desa yang menjadi lokasi penyelenggaraan kegiatan KKN, yaitu Desa Bleberan, Kecamatan Playen, Gunungkidul, D.I. Yogyakarta. Hasil tanaman pangan dengan komoditas terbesar di desa ini adalah tanaman jagung. Hal tersebut dapat dilihat sebagai sebuah potensi yang cukup besar bagi masyarakat Desa Bleberan. Salah satu produk yang sangat mungkin dihasilkan dari tanaman jagung, yaitu produk makanan. Tanaman jagung yang mudah diolah juga memungkinkan masyarakat desa untuk melakukan proses pengolahannya secara mandiri. Oleh karena itu, peranan KKN sebagai perwujudan penerapan pengetahuan tentang pengolahan jagung menjadi penting bagi masyarakat Desa Bleberan. Hal ini bertujuan agar masyarakat desa dapat lebih mengembangkan dan memaksimalkan pengolahan jagung dan memiliki nilai jual yang ekonomis yang dapat membantu membangun perekonomian di Desa Bleberan. Metode yang digunakan dalam jurnal ini yaitu dengan jenis penelitian bersifat kualitatif. Metode pengumpulan sumber data yang digunakan ialah menggunakan metode pengumpulan data sekunder yang dikumpulkan melalui internet, dokumentasi percakapan tim penulis melalui sarana online seperti Whatsapp grup dan Microsoft Teams, serta referensi dari sumber-sumber lain.
\end{abstract}

Kata Kunci-Peranan KKN, Olahan Jagung, Desa Bleberan

\section{PENDAHULUAN}

Kuliah Kerja Nyata atau KKN merupakan kegiatan pendidikan pada perguruan tinggi yang diselenggarakan secara langsung di luar kampus [1]. KKN juga dapat diklasifikasikan sebagai bentuk kegiatan akademik yang berkaitan dengan program pengabdian masyarakat. Aktivitas KKN biasanya dilakukan secara interdisipliner dan intrakurikuler. Artinya, KKN melibatkan hampir semua bidang ilmu yang ditempuh mahasiswa di perguruan tinggi dan dilakukan untuk meninjau realitas secara langsung di masyarakat. Pada proses kegiatan KKN, mahasiswa memiliki tanggung jawab untuk dapat mengidentifikasi, menganalisis, dan menciptakan solusi pada permasalahan pembangunan yang dihadapi oleh sebuah desa. KKN juga bertujuan untuk meningkatkan relevansi antara pendidikan tinggi dan kebutuhan masyarakat [1]. Sektor yang menjadi fokus mahasiswa dari proses kegiatan KKN yang terutama, yaitu sektor pembangunan dan perkembangan sumber daya.

Salah satu desa yang menjadi lokasi penyelenggaraan kegiatan KKN, yaitu Desa Bleberan, Kecamatan Playen, Gunungkidul, D.I. Yogyakarta. Desa Bleberan termasuk ke dalam salah satu desa wisata yang ada di Kabupaten Gunungkidul. Desa Bleberan diperkirakan memiliki luas wilayah sebesar 16.262.170 hektar dengan jumlah dusun sebanyak 11, Rukun Warga (RW) sebanyak 11, dan Rukun Tetangga (RT) sebanyak 85 [2]. Data pada tahun 2014 menunjukkan bahwa Desa Bleberan dihuni oleh sekitar 4.675 jiwa [2]. Jenis pekerjaan masyarakat Desa Bleberan didominasi oleh pekerjaan pada sektor pertanian.

Merujuk pada data dari website resmi Desa Bleberan [3], hasil tanaman pangan dengan komoditas terbesar di desa ini adalah tanaman jagung. Hal tersebut dapat dilihat sebagai sebuah potensi yang cukup besar bagi masyarakat Desa Bleberan. Salah satu produk yang sangat mungkin dihasilkan dari tanaman jagung, yaitu produk makanan. Tanaman jagung yang mudah diolah juga memungkinkan masyarakat desa untuk melakukan proses pengolahannya secara mandiri. Pengolahan jagung hingga menjadi berbagai produk makanan dapat menjadi peluang pekerjaan bagi masyarakat Desa Bleberan. Berdasarkan data dari website resmi Desa Bleberan, jumlah masyarakat desa yang belum/tidak bekerja terbilang masih cukup tinggi, yaitu mencapai 1.154 jiwa [4].

Oleh karena itu, peranan KKN sebagai perwujudan penerapan pengetahuan tentang pengolahan jagung menjadi penting bagi masyarakat Desa Bleberan. Hal ini bertujuan agar masyarakat desa mendapatkan pengetahuan tentang 
Peranan KKN sebagai Perwujudan Penerapan Pengetahuan Tentang Pengolahan Jagung kepada Masyarakat Desa Bleberan, Kabupaten Gunungkidul

pengolahan tanaman jagung menjadi produk makanan. Jika diproyeksikan dalam jangka panjang, maka masyarakat Desa Bleberan mampu membangun ekonomi desanya dengan lebih baik lagi serta saling memberdayakan lewat berbagai peluang kerja baru.

\section{Metode Pengabdian}

Lokasi yang terpilih dalam penelitian ini yaitu Desa Bleberan, Playen, Gunung Kidul dengan objek penelitiannya ialah potensi yang dimiliki oleh desa tersebut yang dijadikan keunggulan dan bisa menjawab permasalahan yang terdapat pada desa tersebut. Metode penelitian dalam penelitian di Desa Bleberan yaitu dengan jenis penelitian bersifat kualitatif. Metode pengumpulan sumber data yang digunakan ialah menggunakan metode pengumpulan data sekunder yang dikumpulkan melalui internet, dokumentasi percakapan tim penulis melalui sarana online seperti Whatsapp grup dan Microsoft Teams, serta referensi dari sumber-sumber lain.

Penelitian di Desa Bleberan ini mempunyai tahapantahapan pada setiap prosesnya yang nantinya hendak membuahkan suatu hasil. Pada kegiatan penelitian ini bertujuan untuk memajukan perekonomian warga, paling utama pada wilayah pedesaan dengan membagikan penyuluhan mengenai "Peranan KKN sebagai Perwujudan Penerapan Pengetahuan Tentang Pengolahan Jagung kepada Masyarakat Desa Bleberan, Gunung Kidul". Berikut merupakan beberapa tahap yang dapat dilakukan:

\section{Meninjau Lokasi}

Pada tahap ini hal yang bisa dilakukan yaitu dengan mengunjungi daerah ataupun desa yang hendak diberikan penyuluhan. Namun karena adanya pandemi Covid-19, maka tidak bisa melakukan kunjungan daerah. Walaupun tidak bisa melakukan kunjungan, pada tahap ini tetap disuguhkan banyak hal yang bisa dilihat serta dianalisis, seperti melihat potensi dari penduduk yang ada serta bagaimana keseharian penduduk di sana apakah sesuai untuk dilakukan penyuluhan tersebut. Tidak hanya dari segi penduduknya, terdapat perihal yang tidak kalah berarti untuk dilakukan observasi yakni letak daerah geografisnya, apakah cocok untuk melaksanakan kegiatan pengolahan jagung ataupun tidak. Dari letak geografis pula bisa menjadi pertimbangan pada saat penerapannya, seperti hendak memakai alat seperti apa dan penentuan bahan-bahan pendukung lainya.

\section{Sumber data}

Setelah mengidentifikasi masalah atau potensi pada desa, pengumpulan data dilakukan. Pengumpulan data dilakukan dengan mencari berbagai informasi yang relevan dengan topik yang berkaitan dengan potensi hasil alam Desa Bleberan. Sumber data yang dilakukan oleh kelompok merupakan data sekunder. Data dan informasi yang didapatkan diakses melalui internet yaitu website, artikel, jurnal, buku, skripsi, dan lain-lain.

a. Website berita, artikel

Website berita dan artikel yang ada di internet merupakan hal yang paling relevan dengan kondisi desa. Lewat itu, kelompok mendapatkan informasi mengenai kondisi atau status yang terjadi di desa dalam beberapa tahun ini.

b. Jurnal

Jurnal yang digunakan kelompok sebagai sumber merupakan jurnal penelitian yang relevan dengan topik kegiatan KKN kelompok agar mendapatkan informasi atau data yang valid untuk mencapai tujuan dari KKN yang dilakukan di Desa Bleberan. Data digunakan sebagai acuan untuk menemukan pemecahan permasalahan.

c. Website desa

Sumber data lain diperoleh dari website Desa Bleberan yaitu (https://www.bleberanplayen.desa.id/first) meliputi data seperti profil desa, kondisi geografis desa, pekerjaan penduduk desa, serta potensi yang dimiliki desa.

\section{Mengumpulkan Alat dan Bahan}

Perlengkapan serta bahan yang hendak digunakan pada proses pengolahan jagung disesuaikan dengan kebutuhan. Alat yang digunakan mudah didapatkan seperti: panci, loyang, sendok makan, sendok teh, mangkuk, piring, tusuk sate, dan blender. Kemudian bahan yang digunakan juga mudah didapatkan seperti: jagung, telur, tepung terigu, daun bawang, bawang putih bubuk, garam, lada, dan saus sambal.

\section{Memulai Pembuatan}

Proses mengelola jagung yang kemudian diolah menjadi makanan yang memiliki nilai jual yang ekonomis tidak terlalu sulit, hanya saja membutuhkan kesabaran dan ketelitian saat mengolahnya. Sate jagung adalah salah satu makanan yang berbahan dasar jagung dan memiliki nilai jual. Selain itu, olahan makanan tersebut sehat untuk dikonsumsi karena memiliki nilai gizi yang tinggi karena memiliki banyak kandungan serat, protein, karbohidrat kompleks, mineral, vitamin dan antioksidan. Hasil olahan dari jagung ini diyakini memiliki banyak manfaat untuk kesehatan.

Proses pembuatan sate jagung diawali dengan mengupas jagung lalu memisahkan biji jagung dari batangnya. Setelah itu biji jagung diblender sampai halus lalu dicampurkan ke berbagai bahan yang telah disiapkan. Kemudian tuangkan ke dalam cetakan dan kukus hingga matang. Berikutnya tusuk cetakan jagung tersebut seperti sate, lalu sate jagung sudah siap disajikan.

\section{Jenis Program Kerja}

Bentuk luaran (output) program kerja KKN adalah berbentuk ebook dan video. Ebook dibuat berdasarkan tema yang telah ditentukan dengan program kerja masingmasing topik yang telah ditentukan. Ebook dibuat dengan kalimat yang jelas, padat, serta memberikan informasi yang tepat sehingga dapat dipahami dengan mudah oleh para pembaca. Video dibuat juga berdasarkan tema program kerja masing-masing topik. Video dibuat menggunakan aplikasi powtoon. 
Peranan KKN sebagai Perwujudan Penerapan Pengetahuan Tentang Pengolahan Jagung kepada Masyarakat Desa Bleberan, Kabupaten Gunungkidul

\section{HASIL DAN PEMBAHASAN}

Penerapan pengetahuan yang dapat diperoleh bagi warga desa Bleberan dari hasil kegiatan KKN ini adalah tentang bagaimana cara mengelola hasil komoditas tani yaitu jagung mentah yang dapat dikelola menjadi berbagai macam olahan makanan dengan memiliki nilai jual yang ekonomis. Olahan makanan tersebut dapat diolah menjadi makanan ringan maupun makanan berat, Dilihat dari data tabel pada situs website potensi desa Bleberan jumlah penduduk berdasarkan jenis pekerjaan diketahui bahwa pekerjaan yang paling tinggi adalah petani dan yang tidak atau belum bekerja [5]. Sehingga dengan penerapan pengetahuan ini bisa saling memberikan keuntungan antara para petani Jagung dan warga desa yang belum bekerja. Masing-masing dapat membantu menaikkan dan menambah pendapatan yang sama-sama saling menguntungkan.

Para warga desa yang belum memiliki pekerjaan dapat membeli jagung mentah pada petani jagung kemudian mengolah menjadi makanan atau camilan yang dapat dijual kepada warga desa sendiri atau dijual di luar desa dengan membuka kedai jualan, hal ini tentu dapat menaikkan pendapatan warga desa Bleberan, terlebih camilan atau makanan ringan paling diminati kalangan orang dewasa maupun anak-anak dengan cita rasa yang menggugah selera. Untuk mendapatkan keuntungan tentunya warga desa harus memiliki konsisten dalam berjualan dan giat mengolah hasil jagung ini, tidak hanya sehari dua hari dalam berjualan tetapi setiap harinya, tentunya dengan hal tersebut dapat memberikan dampak positif dan mengurangi angka pengangguran pada desa Bleberan.

Selain itu dari segi gizi, jagung memiliki banyak kandungan serat, protein, karbohidrat kompleks, mineral, vitamin dan antioksidan. Jagung juga memiliki banyak manfaat untuk kesehatan seperti, Melancarkan saluran pencernaan dan mencegah sembelit. Menyehatkan mata dari gangguan mata terkait penuaan, seperti degenerasi makula dan katarak, meningkatkan kepadatan tulang, terutama bagi orang yang sulit mencerna susu atau memiliki alergi susu atau intoleransi laktosa, Mencegah depresi, Mengendalikan tekanan darah, mengonsumsi jagung secara rutin dapat memberi manfaat mencegah penyakit darah tinggi. Namun, jagung sebaiknya tidak ditambah garam berlebih karena asupan garam yang berlebihan justru dapat meningkatkan tekanan darah dan Menangkal radikal bebas yang dapat meningkatkan risiko terkena penyakit serta penuaan dini [6].

Camilan sate jagung dan telur merupakan olahan makanan yang berbahan dasar jagung dengan campuran telur dan beberapa bumbu rempah lainnya yang akan menambah cita rasa dari camilan ini. Berikut cara olahan jagung mentah yang dapat dikelola menjadi olahan makanan yang rasanya enak, mudah dibuat dan memiliki nilai jual yang ekonomis :

1. Bahan-bahan yang perlu disiapkan
a. 2 buah jagung manis
b. 1 butir telur
c. 5 sendok makanan tepung terigu
d. 1 batang daun bawang
e. 1 sendok teh bawang putih bubuk
f. $1 / 2$ sendok teh garam
g. $1 / 4$ sendok teh lada bubuk
h. tusuk sate

2. Cara pembuatan :

a. Kupas jagungnya, lalu pisahkan biji jagung dari batangnya.

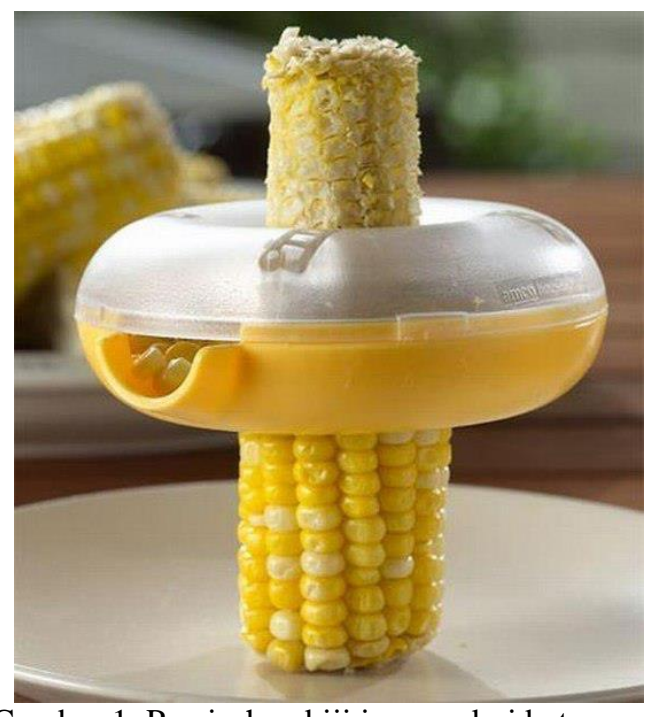

Gambar 1. Pemisahan biji jagung dari batangnya

b. Siapkan blender, lalu masukan biji jagung dan telur ke dalam blender tanpa tambahan air. Kemudian di blender hingga halus.

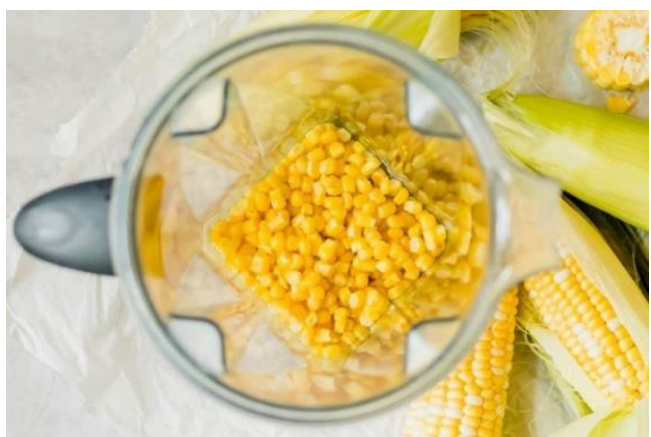

Gambar 2. Biji jagung dimasukkan ke blender

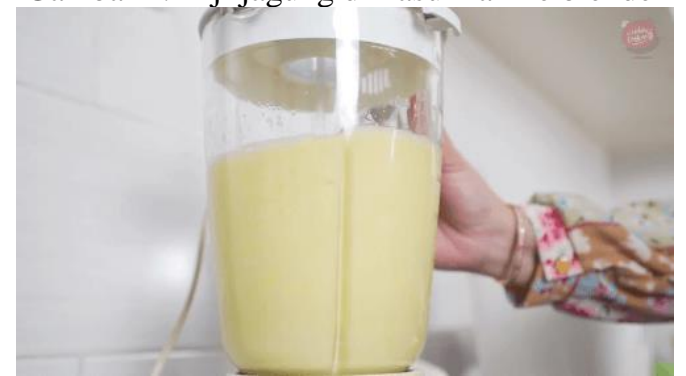

Gambar 3. Biji jagung dan telur sudah dihaluskan 
Peranan KKN sebagai Perwujudan Penerapan Pengetahuan Tentang Pengolahan Jagung kepada Masyarakat Desa Bleberan,

c. Setelah itu, keluarkan adonan jagung yang telah halus di wadah mangkok sedang.

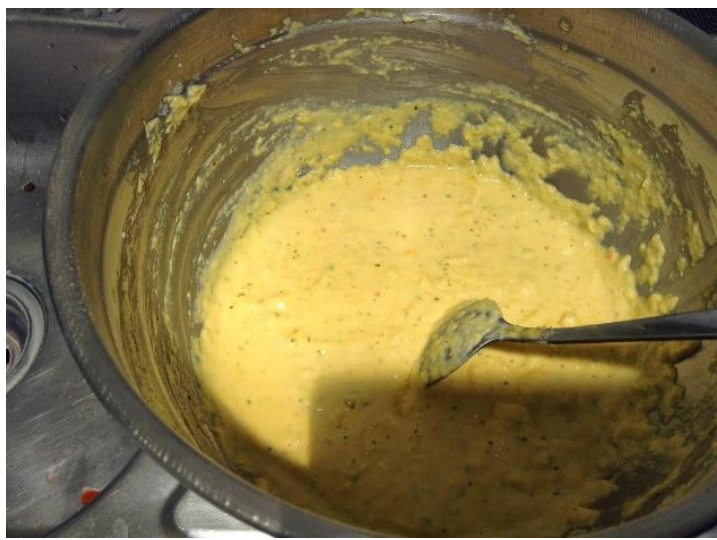

Gambar 4. Adonan jagung dipindahkan ke dalam mangkok

d. Campurkan tepung terigu, daun bawang yang telah diiris, bawang putih bubuk, garam dan lada lalu diaduk menjadi satu sampai semua bahan tercampur menjadi satu.

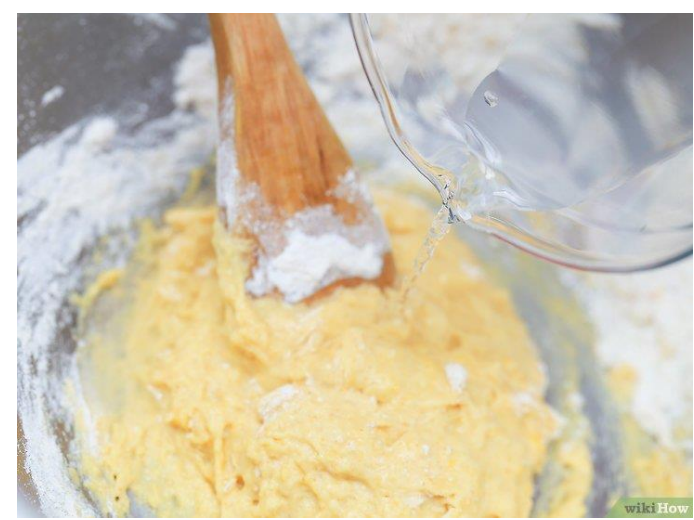

Gambar 5. Pencampuran adonan dan bahan lainnya

e. Masukkan campuran tadi ke dalam cetakan atau loyang.

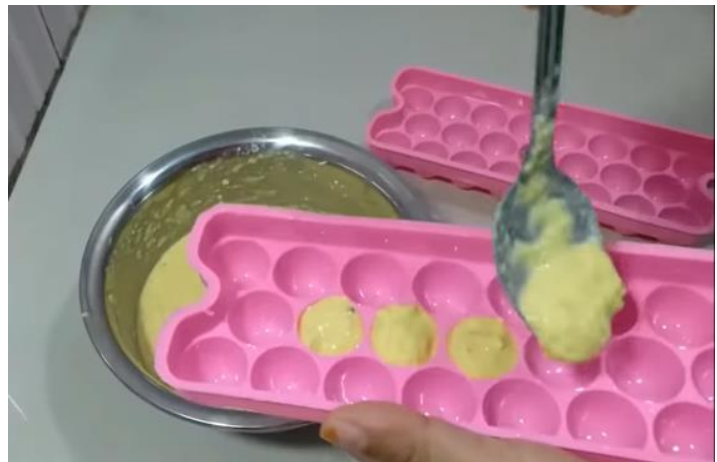

Gambar 6. Campuran adonan dimasukkan ke dalam cetakan f. Kukus di dalam panci hingga matang.

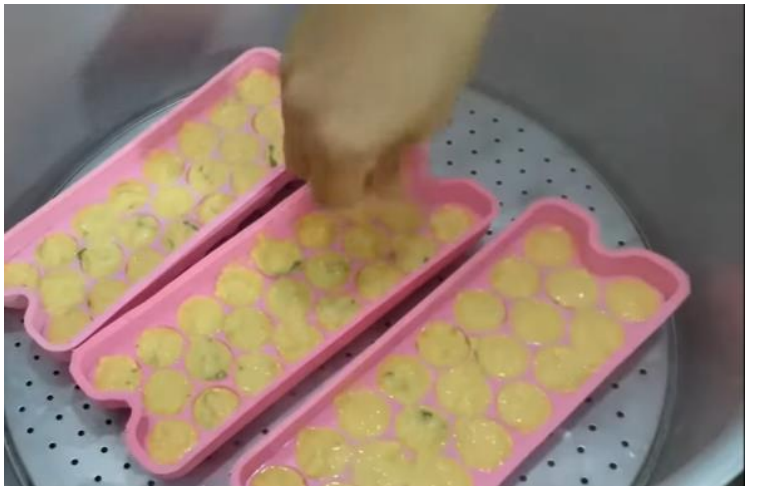

Gambar 7. Loyang berisi campuran adonan dimasukkan ke dalam panci kukusan

g. Setelah matang angkat dan keluarkan dari cetakan atau loyang.

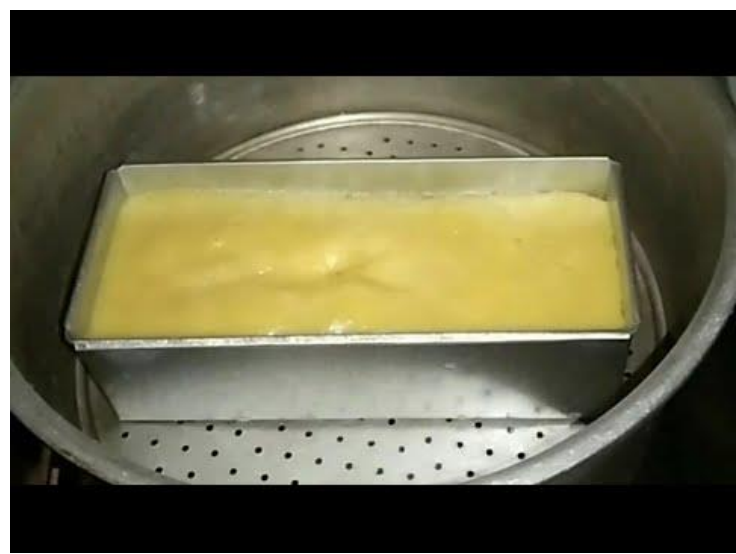

Gambar 8. Campuran adonan yang sudah matang

h. Tusuk adonan yang telah matang pada tusukan sate.

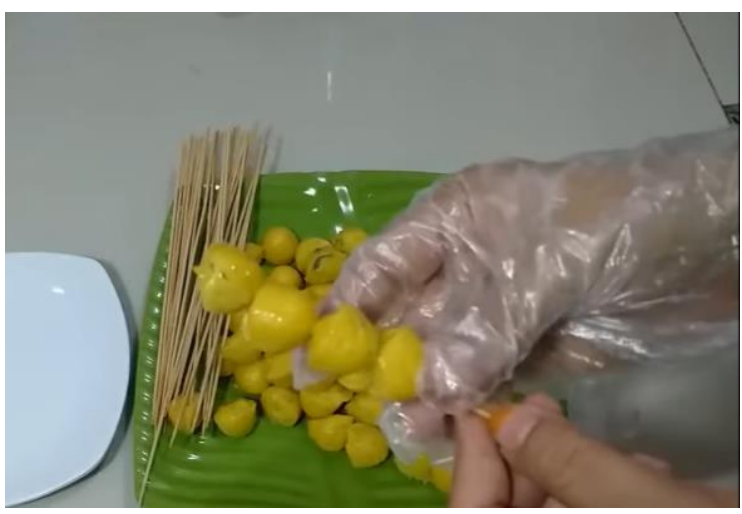

Gambar 9. Campuran adonan yang sudah matang ditusuk menggunakan tusuk sate 
Peranan KKN sebagai Perwujudan Penerapan Pengetahuan Tentang Pengolahan Jagung kepada Masyarakat Desa Bleberan,

i. Sate jagung telur dapat dinikmati dengan saus sambal.

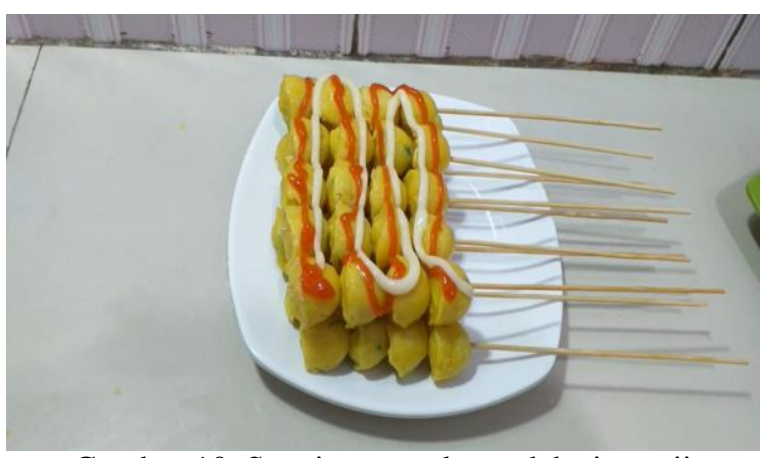

Gambar 10. Sate jagung telur sudah siap saji

Dari cara pembuatan di atas, tentunya sangat mudah dan tidak membutuhkan banyak alat dan bahan yang menguras kantong sehingga warga desa yang memiliki modal kecil dapat membuat usaha jualan camilan sate jagung telur ini. Diharapkan pula dapat membantu memberikan pengetahuan kepada warga desa Bleberan untuk bisa berinovasi dalam membuat olahan makanan dari jagung, terlebih camilan ini sangat disukai oleh orang dewasa maupun anak-anak, sehingga memiliki nilai jual yang ekonomis dan dapat membantu meningkatkan pendapatan dan perekonomian masyarakat desa Bleberan, selain dengan cara menjual jagung masih dalam bentuk mentah.

\section{KESIMPULAN}

Kuliah Kerja Nyata (KKN) merupakan bentuk kegiatan akademik yang berkaitan dengan program pengabdian masyarakat. Dalam proses kegiatan KKN, mahasiswa bertanggung jawab akan menganalisis permasalahan yang ada di desa dan berusaha memberikan solusi terhadap permasalahan itu sehingga dapat membangun desa dengan baik di masa depan Salah satu desa yang menjadi lokasi penyelenggaraan kegiatan KKN, yaitu Desa Bleberan, Kecamatan Playen, Gunungkidul, D.I. Yogyakarta.

Desa Bleberan termasuk ke dalam salah satu desa wisata yang ada di Kabupaten Gunungkidul. Jenis pekerjaan masyarakat Desa Bleberan didominasi oleh pekerjaan pada sektor pertanian. Desa Bleberan memiliki komoditas yang cukup besar di hasil tanaman pangan jagung. Ini menjadi potensi yang besar bagi masyarakat Desa Bleberan. Hal tersebut menjadi acuan bagi kelompok untuk mengembangkan potensi hasil tanaman pangan jagung di Desa Bleberan seperti memberitahu contoh olahan jagung, cara pembuatan, dan pentingnya untuk berkreasi dalam mengolah jagung menjadi olahan jagung yang dapat dijual dan membantu meningkatkan pendapatan dan perekonomian masyarakat desa Bleberan selain dengan cara menjual jagung yang masih dalam bentuk mentah.

Kegiatan Kuliah Kerja Nyata yang dilakukan oleh mahasiswa berperan sebagai perwujudan penerapan pengetahuan tentang pengolahan dari hasil tanaman pangan jagung bagi masyarakat Desa bleberan. Sehingga masyarakat Desa bleberan dapat menerapkan pengetahuan yang diperoleh untuk lebih dapat mengembangkan dan memaksimalkan pengolahan jagung yang ada di desa dan memiliki nilai jual yang ekonomis yang dapat membantu membangun perekonomian di Desa Bleberan.

\section{UCAPAN TERIMAKASIH}

Kelompok mengucapkan terima kasih kepada LPPM Universitas Atma Jaya sebagai penyelenggara kegiatan.

\section{DAFTAR PUSTAKA}

[1] F. Anasari, A. Suyatno, and I. F. Astuti, "Sistem Pelaporan Terpadu Kuliah Kerja Nyata Berbasis Digital (Studi Kasus: Lembaga Pengabdian Kepada Masyarakat Universitas Mulawarman)," J. Inform. Mulawarman, vol. 10, no. 1, pp. 11-19, Feb. 2015, Accessed: May 25, 2021. [Online]. Available: http://ejournals.unmul.ac.id/index.php/JIM/article/view/18/pdf.

[2] F. Sidik, "Menggali Potensi Lokal Mewujudkan Kemandirian Desa," J. Kebijak. Adm. Publik, vol. 19, no. 2, pp. 115-131, Nov. 2015, Accessed: May 26, 2021. [Online]. Available:

https://journal.ugm.ac.id/jkap/article/view/7962/6528.

[3] "Profil Desa Bleberan - Website Bleberan." https://www.bleberan-playen.desa.id/first/artikel/32 (accessed Apr. 29, 2021).

[4] Kalurahan Bleberan, "Website Bleberan." https://www.bleberan-playen.desa.id/first/statistik/pekerjaan (accessed May 25, 2021).

[5] Suarni and H. Subagio, "Potensi Pengembangan Jagung Dan Sorgum Sebagai Sumber Pangan Fungsional," Jurnal Penelitian dan Pengembangan Pertanian, vol. 32, no. 2, pp. 47-55, 2014.

[6] " ini sederet manfaat jagung bagi kesehatan-website Alodokter". https://www.alodokter.com/manfaat-jagung$\underline{\text { tidak-terbatas-pada-bijinya }}$

[7]M. Ina, "Resep Camilan Jagung dan Telur ala Mama Ina," 21 April 2021. [Online]. Available: https://mamaina.id/resepjajanan/resep-camilan-jagung-dan-telur-ala-mama-ina/.

[Accessed 27 May 2021].

[8] Masniah and Syamsuddin, "Pemanfaatan Jagung Dalam Pembuatan Aneka Macam Olahan Untuk Memperkuat Ketahanan Pangan," Seminar Nasional Serealia, pp. 537-542, 2013. 
Peranan KKN sebagai Perwujudan Penerapan Pengetahuan Tentang Pengolahan Jagung kepada Masyarakat Desa Bleberan, Kabupaten Gunungkidul

[9] A. Ratna, A. Robet, and R. Nur, "Penganekaragaman Pangan Olahan Jagung dan Analisis Kelayakan Secara Ekonomi di Kecamatan Pekalongan Kabupaten Lampung Timur," Prosiding Seminar Nasional Swasembada Pangan Politeknik Negeri Lampung, pp. 161-169, 2015.

[10] R. Elly, S. Dwi, M. Gatot, A. Arfan, and L. Fitri, "Pengolahan Pangan Berbahan Dasar Jagung Menjadi Berbagai Produk Makanan," Jurnal Pengabdian Sriwijaya, pp. 247-250, 2015.

\section{PENULIS}

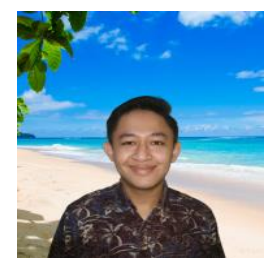

\author{
Aldidarichie Prindi Chandra \\ prodi Teknik Sipil, Fakultas \\ Teknik, Universitas Atma Jaya \\ Yogyakarta.
}

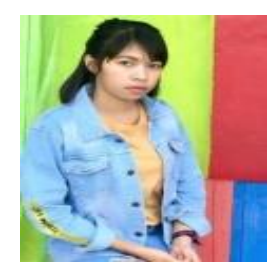

Beatrix Oktaviani Towa, prodi Sosiologi, Fakultas Ilmu Sosial dan Ilmu Politik, Universitas Atma Jaya Yogyakarta.

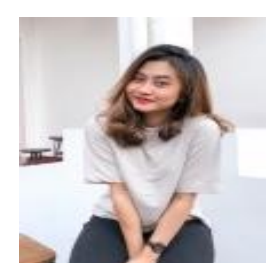

Devineta Niken Salsabilla, prodi Ilmu Komunikasi, Fakultas Ilmu Sosial dan Ilmu Politik, Universitas Atma Jaya Yogyakarta.

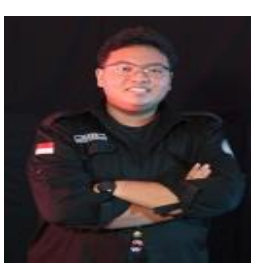

Galang Ariesta Nugraha, prodi Teknik Industri, Fakultas Teknologi Industri, Universitas Atma Jaya Yogyakarta.

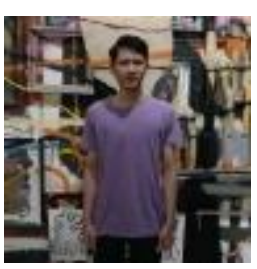

prodi Manajemen, Fakultas Bisnis dan Ekonomi, Universitas Atma Jaya Yogyakarta.

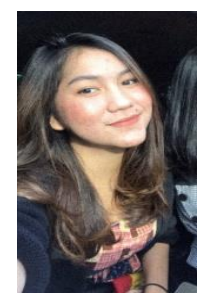

Lidya Christine Pasaribu, prod Sosiologi, Fakultas Ilmu Sosial dan Ilmu Politik, Universitas Atma Jaya Yogyakarta.

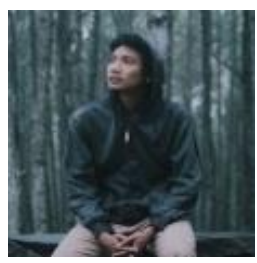

Pramana Anantasadhu, prodi Sistem Informasi, Fakultas Teknologi Industri, Universitas Atma Jaya Yogyakarta.

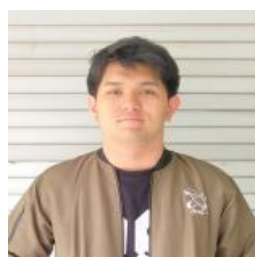

Sandy Marcellino, prodi Teknik Informatika, Fakultas Teknologi Industri, Universitas Atma Jaya Yogyakarta.

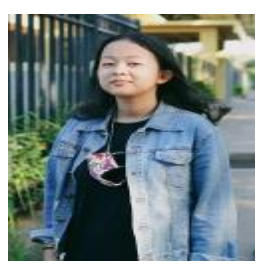

Valencia Yuniarti Sutjiato, prodi Ilmu Komunikasi, Fakultas Ilmu Sosial dan Ilmu Politik, Universitas Atma Jaya Yogyakarta.

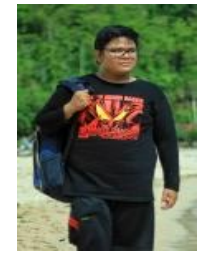

Valens Karel Bramasta, prodi Ilmu Hukum, Fakultas Hukum, Universitas Atma Jaya Yogyakarta.

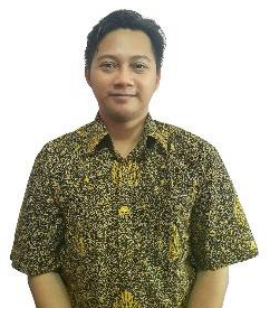

Didit Gunawan Prasetyo Jati, prodi Teknik Sipil, Fakultas Teknik, Universitas Atma Jaya Yogyakarta. 